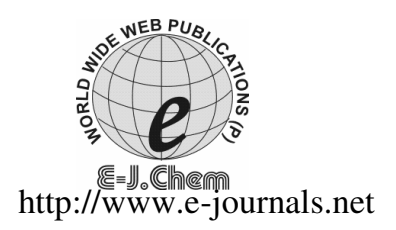

ISSN: 0973-4945; CODEN ECJHAO

E-Journal of Chemistry

2010, 7(4), 1507-1513

\title{
Spectrophotometric Methods for the Assay of Pyrilamine Maleate Using Chromogenic Reagents
}

\author{
V. ANNAPURNA, G. JYOTHI, V. NAGALAKSHMI and B.B.V. SAILAJA* \\ Department of Chemistry, St. Theresa's College for Women, Eluru-534003, India. \\ *Andhra University, Visakhapatnam, India. \\ sailaja_bbv@yahoo.co.in
}

Received 28 July 2009; Revised 31 December 2009; Accepted 25 February 2010

\begin{abstract}
Simple, accurate and reproducible UV spectrophotometric methods were established for the assay of pyrilamine maleate (PYRA) based on the formation of oxidative coupling and precipitation, charge transfer complexation products. Method A includes the oxidative coupling reaction of PYRA with 3-methyl-2benzathiazolinone hydrazone (MBTH) in presence of $\mathrm{Ce}(\mathrm{IV})$. The formation of oxidative coupling product with 4-amino phenazone (4-AP) in presence of $\mathrm{K}_{3} \mathrm{Fe}(\mathrm{CN})_{6}$ is incorporated in method B. Precipitation/charge transfer complex formation of the PYRA with tannic acid (TA)/Metol-Cr(VI) in method C were proposed. The optical characteristics such as Beers law limits, molar absorptivity and Sandell's sensitivity for the methods (A-C) are given. Regression analysis using the method of least squares was made to evaluate the slope (b), intercept (a) and correlation coefficient (r) and standard error of estimation (Se) for each system. Determination of pyrilamine in bulk form and in pharmaceutical formulations were also incorporated.
\end{abstract}

Keywords: Estimation, Pyrilamine, Precipitating agent, Charge transfer complex.

\section{Introduction}

Pyrilamine (as maleate PYRA) is an antihistamine with a low incidence of side effects. It is effective for use in perennial and seasonal allergic rhinitis, vasomotor rhinitis, allergic conjunctivitis due to inherent allergens and foods, mild uncomplicated allergic skin manifestations of urticarea and angiodesma, angioedema, demographism and aneceoratum of reactions of blood or plasma. It is an antagonizing agent that competes for receptor sites with natural histamine, a biogenic amine present in most body cells and tissues.

A very few physicochemical methods appeared in the literature for the assay of PYRA ${ }^{1}$ in biological fluids and pharmaceutical formulations. Most of them are based on visible spectrophotometric methods ${ }^{2-3}$, HPLC $^{4-8}$, GC $^{9-10}$, fluorimetry ${ }^{11-13}$, LC-MS $^{14}$, GC-MS $^{15-17}$, \& $\mathrm{TLC}^{18}$, Mass ${ }^{19}$. The analytically useful functional groups in PYRA have not been fully 
exploited for designing suitable visible spectrophotometric methods and so still offer a scope to develop few more visible spectrophotometric methods with better sensitivity, selectivity, precision and accuracy. The author has made some attempts in this direction and succeeded in developing visible spectrophotometric methods by exploiting various functional groups of PYRA. All these methods have been extended to pharmaceutical formulations as well.

\section{Experimental}

An Elico, UV - Visible digital spectrophotometer with $1 \mathrm{~cm}$ matched quartz cells were used for the spectral and absorbance measurements. An Elico LI-120 digital pH meter was used for $\mathrm{pH}$ measurements.

All the chemicals and reagents used were analytical grade and the aqueous solutions were freshly prepared with triple distilled water. A $1 \mathrm{mg} / \mathrm{mL}$ solution was prepared by dissolving $100 \mathrm{mg}$ of pure PYRA in $100 \mathrm{~mL}$ distilled water and the stock solution was diluted step wise with distilled water to get the working standard solutions of required concentrations. MBTH Solution (Aldrich; $0.2 \%, 8.56 \times 10^{-3} \mathrm{M}$ ), Ce(IV) Solution (Wilson labs; $1 \%, 1.58 \times 10^{-2} \mathrm{M}$ ) for method A 4-AP solution (Ferak; $\left.1 \%, 4.92 \times 10^{-2} \mathrm{M}\right), \mathrm{K}_{3}\left[\mathrm{Fe}(\mathrm{CN})_{6}\right]\left(\mathrm{BDH} ; 4.0 \%, 1.22 \times 10^{-1} \mathrm{M}\right)$, Pyridine (Qualigens, $12.4 \mathrm{M}$ ) for methodB and TA (Loba $0.2 \%, 1.17 \times 10^{-3} \mathrm{M}$ ); PMAP (Loba, $\left.0.3 \%, 8.71 \times 10^{-3} \mathrm{M}\right), \mathrm{Cr}(\mathrm{VI})\left(\mathrm{BDH}, 0.3 \% 1.01 \times 10^{-2} \mathrm{M}\right)$, Buffer $\mathrm{pH} 3$ were prepared.

\section{Recommended procedures}

\section{Method A}

Aliquots of standard PYRA solution $\left(0.5-3.0 \mathrm{~mL}, 25 \mu \mathrm{g} \cdot \mathrm{mL}^{-1}\right)$ were transferred into a series of $25 \mathrm{~mL}$ calibrated tubes. Then $0.5 \mathrm{~mL}\left(8.56 \times 10^{-3} \mathrm{M}\right)$ of MBTH solution was added and kept aside for $5 \mathrm{~min}$. After that $1 \mathrm{~mL}\left(1.58 \times 10^{-2} \mathrm{M}\right)$ of ceric ammonium sulphate was added and kept aside for $10 \mathrm{~min}$. The volume was made up to the mark with distilled water. The absorbance was measured at $460 \mathrm{~nm}$ against a similar reagent blank. The amount of PYRA was computed from its calibration graph (Figure 1).

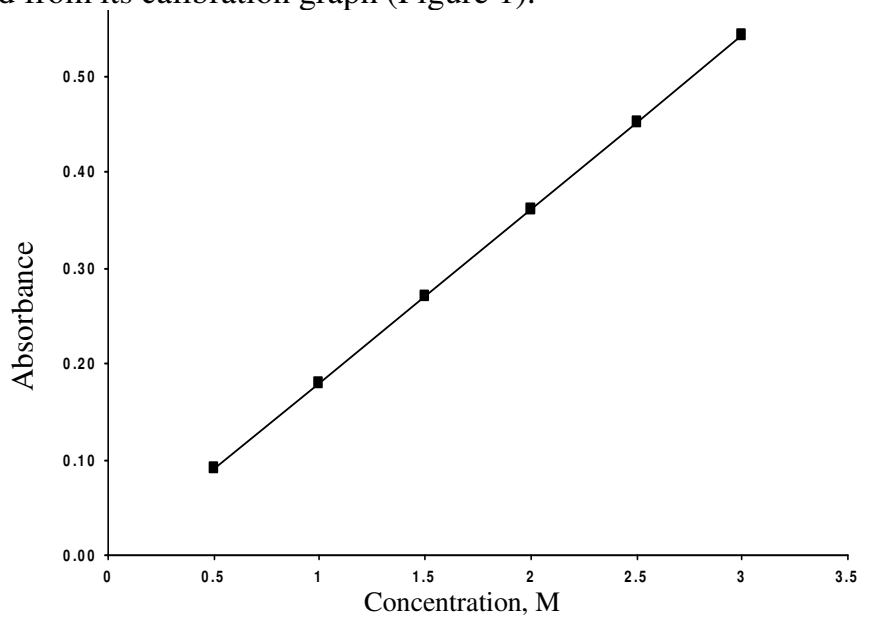

\section{Method B}

Figure 1. Beer's law plot of PYRA - MBTH-Ce(IV)

Aliquots of standard PYRA $\left(0.5-3.0 \mathrm{~mL}, 25 \mu \mathrm{g} . \mathrm{mL}^{-1}\right)$ solution, $0.5 \mathrm{~mL}$ of pyridine, $1 \mathrm{~mL}$ of $4 \mathrm{AP}\left(4.92 \times 10^{-2} \mathrm{M}\right)$ and $0.5 \mathrm{~mL}$ of $\mathrm{K}_{3}\left[\mathrm{Fe}(\mathrm{CN})_{6}\right]\left(1.22 \times 10^{-1} \mathrm{M}\right)$ were added successively into a series of 10 graduated tubes and the total volume in each flask was brought to $10 \mathrm{~mL}$ with distilled water and kept aside for $5 \mathrm{~min}$. The absorbances were measured at $500 \mathrm{~nm}$ against a reagent blank. The coloured species was stable for $30 \mathrm{~min}$. The drug concentration was deduced from a calibration graph (Figure 2). 


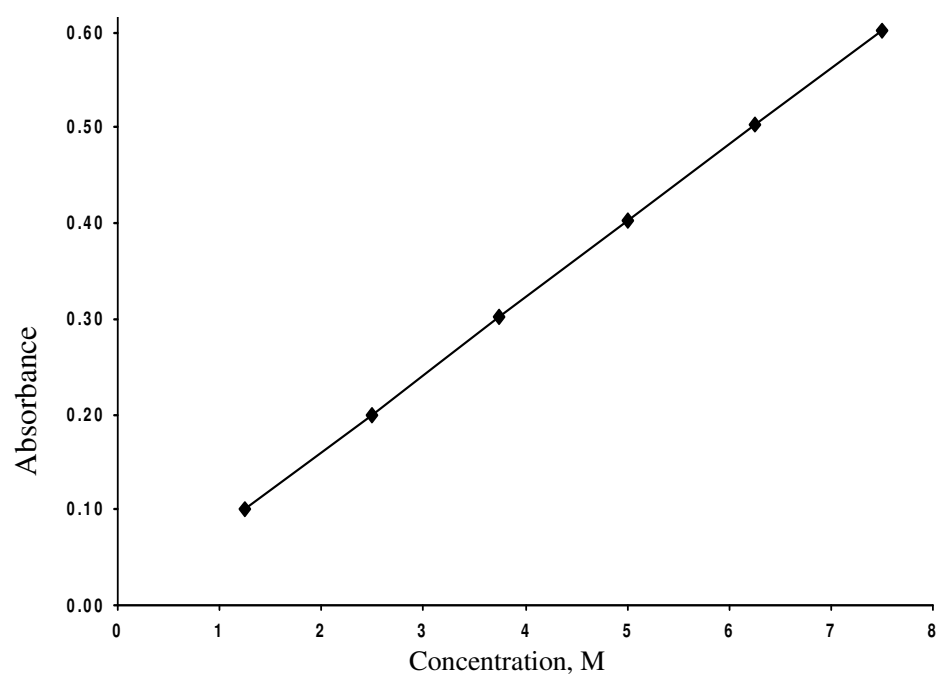

Method C

Figure 2. Beer's law plot of PYRA - 4-AP $-\mathrm{K}_{3} \mathrm{Fe}(\mathrm{CN})_{6}$

Aliquots of standard drug solution $(0.5-3.0 \mathrm{~mL} 400 \mu \mathrm{g} / \mathrm{mL})$ were delivered in to a series of centrifuge tubes and the volume in each test tube was adjusted to $3.0 \mathrm{~mL}$ with $0.01 \mathrm{~N} \mathrm{HCl}$. Then $1.0 \mathrm{~mL}$ of Tannic acid was added and centrifuged fro $5 \mathrm{~min}$. The precipitate was collected through filtration and subsequently washed with $2.0 \mathrm{~mL}$ of distilled water. The filtrate and washings were collected in a $25 \mathrm{~mL}$ graduated test tube. Then $15 \mathrm{ml}$ of $\mathrm{p}^{\mathrm{H}} 3.0$ buffer and $1.5 \mathrm{~mL}$ of PMAP solution were successively added. After $2 \mathrm{~min}, 2.0 \mathrm{~mL}$ of $\mathrm{Cr}$ (VI) solution was added and the volume was made up to the mark with distilled water. The absorbance was measured after $5 \mathrm{~min}$ at $560 \mathrm{~nm}$ against distilled water. A blank experiment was also carried out omitting the drug. The decrease in absorbance and intern drug concentration was obtained by substracting the absorbance of the test solution from the blank. The amount of drug was calculated from Beer's law plot (Figure 3)

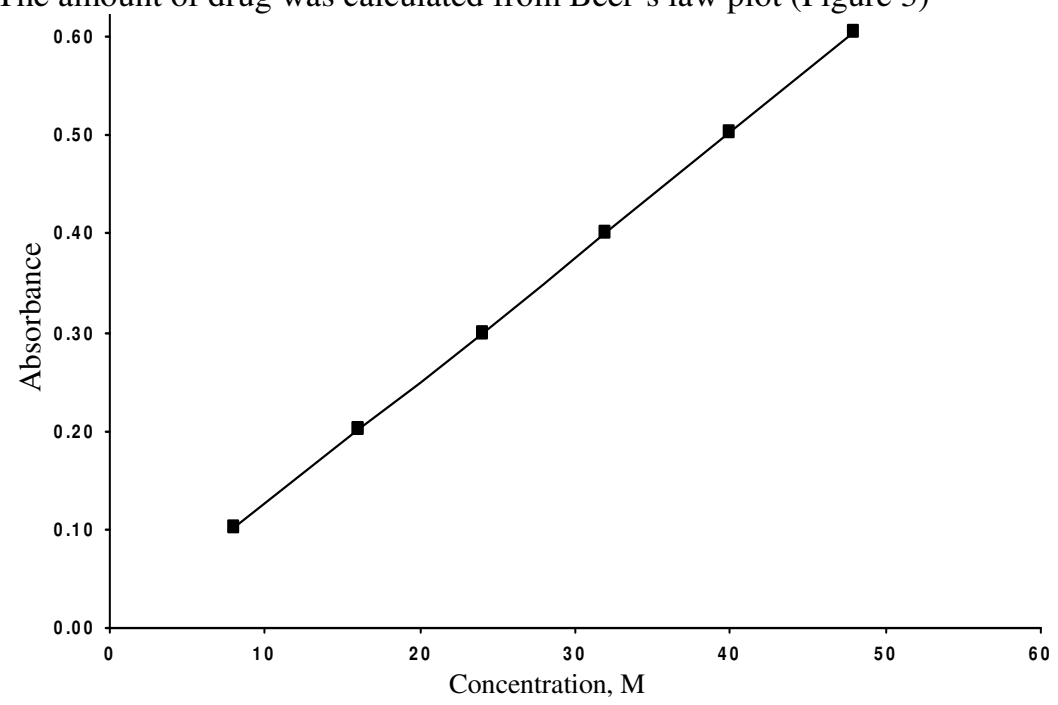

Figure 3. Beer's law plot of PYRA - (TA/PMAP-Cr(VI)) 
Structure of PYRA

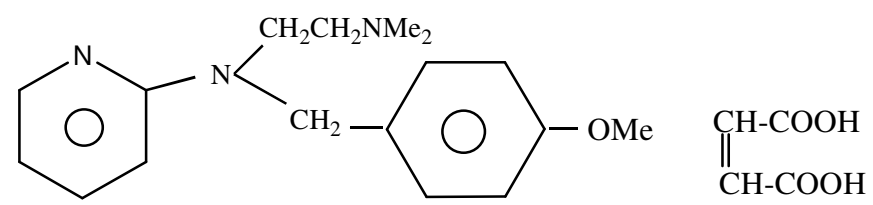

1, 2-Ethanediamine $N$-[(4-methoxy, phenyl) methyl]- $N^{1}, N^{1}$-dimethyl- $N$-2 piridinyl- (Z)2 butenedioate (1:1) 2-[(2-dimethyl amino) ethyl) ( $p$-methoxy benzyl) amino] pyridine maleate $(1: 1)$

\section{Method A}<smiles>Cn1c(=NN)sc2ccccc21</smiles><smiles>Cn1c(=N[NH])sc2ccccc21</smiles><smiles></smiles><smiles>[R]c1ccc(O)c(C(C)(C)C)c1</smiles><smiles>CCCN(CC)c1ccccn1</smiles><smiles></smiles>

\section{Method B}<smiles>Cc1c(N)c(=O)n(-c2ccccc2)n1C</smiles>

4-AP

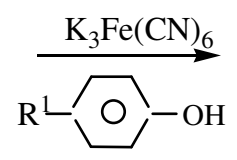<smiles>[R]C1=CC(=NN=c2sc3ccccc3n2C)C(=O)C=C1</smiles>

\section{Method C}

Step I

$$
\mathrm{PYRA}+\mathrm{TA} \rightarrow \underset{(\text { Adduct })}{\mathrm{PYRA}-\mathrm{TA}}+\underset{(\text { Unreacted })}{\mathrm{TA}}
$$


Step II

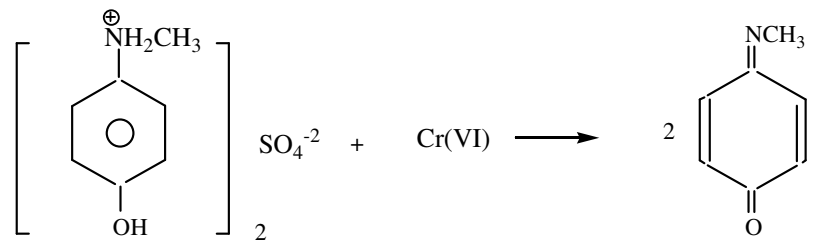<smiles></smiles>

\section{Results and Discussion}

The optimum conditions for the color development of methods A, B and C were established by varying the parameters one at a time, keeping the others fixed and observing the effect produced on the absorbance of the colored species.

The list of proposed and reported methods was given in Table 1. The optical characteristics such as Beers law limits, molar absoptivity and Sandell's sensitivity for the methods (A-C) are given Table 2. Regression analysis using the method of least squares was made to evaluate the slope (b), intercept (a) and correlation coefficient (r) and standard error of estimation (Se) for each system.

The accuracy of the methods was ascertained by comparing the results by proposed and reference methods, statitistically by the $t$ - and $F$ - tests. The comparison shows that there is no significant difference between the results of studied methods and those of the reference ones. The similarity of the results is obvious evidence that during the application of these methods, the excipients are usually present in pharmaceutical formulations do not interfere in the assay of proposed methods. As an additional check of accuracy of the proposed methods, recovery experiments were carried out. The recoveries of the added amounts of standard drug were studied at three different levels. Each level was repeated for 6 times. From the amount of drug found, the $\%$ recovery was calculated. The higher $\lambda_{\max }$ values of all the proposed methods have a decisive advantage since the interference from the associated ingredients should be generally less at higher wavelengths than at lower wavelengths. Thus the proposed visible spectrophotometric methods are simple and sensitive with reasonable precision, accuracy and constitute better alternatives to the existing ones to the routine determination of PYRA in bulk forms and pharmaceutical formulations.

Table 1. List of proposed and reported visible spectrophotometric methods

\begin{tabular}{|c|c|c|c|c|c|}
\hline \multirow[b]{2}{*}{ Type of reaction } & \multirow[b]{2}{*}{ Reagent } & \multirow[b]{2}{*}{ Method } & \multicolumn{3}{|c|}{ Optical characteristics } \\
\hline & & & $\lambda_{\max } \mathrm{nm}$ & $\in_{\max } 1 . \mathrm{mole}^{-1}$ & $\begin{array}{c}\text { Beer's limits } \\
\mu \mathrm{g} \mathrm{mL} \mathrm{m}^{-1}\end{array}$ \\
\hline Oxidative coupling & MBTH -Ce(IV) & Method A & 460 & $7.288 \times 10^{4}$ & $0.5-3.0$ \\
\hline Oxidative coupling & $4 \mathrm{AP}-\mathrm{K}_{3}[\mathrm{Fe}(\mathrm{CN})]_{6}$ & Method B & 500 & $3.103 \times 10^{4}$ & $1.25-7.5$ \\
\hline $\begin{array}{l}\text { Precipitation/charge } \\
\text { transfer complex } \\
\text { formation }\end{array}$ & TA/Metol-Cr(VI) & Method C & 560 & $5.045 \times 10^{3}$ & $8-48$ \\
\hline
\end{tabular}


Table 2. Optical and regression characteristics, precision and accuracy of the proposed methods for PYRA

\begin{tabular}{|c|c|c|c|}
\hline Parameter & Method A & Method B & Method C \\
\hline$\lambda_{\max }, \mathrm{nm}$ & 460 & 500 & 560 \\
\hline Beer's law limits, $\mu \mathrm{g} / \mathrm{mL}$ & $1.0-6.0$ & $1.25-7.5$ & $8-48$ \\
\hline Detection limit, $\mu \mathrm{g} / \mathrm{mL}$ & 0.07374 & 0.06312 & 1.316 \\
\hline Molar absorptivity, $\mathrm{L} \mathrm{mol}^{-1} \cdot \mathrm{cm}^{-1}$ & $2.998 \times 10^{4}$ & $2.971 \times 10^{4}$ & $2.899 \times 10^{3}$ \\
\hline $\begin{array}{l}\text { Sandell's sensitivity }\left(\mu \mathrm{g} . \mathrm{cm}^{-2} / 0.001\right. \\
\text { absorbance unit) }\end{array}$ & $6.486 \times 10^{-2}$ & $6.238 \times 10^{-2}$ & 0.2937 \\
\hline Optimum photometric range, $\mu \mathrm{g} / \mathrm{mL}$ & $2.5-4.5$ & $3.6-7.5$ & $20-48$ \\
\hline Regression equation $(\mathrm{Y}=\mathrm{a}+\mathrm{bc})$ slope $(\mathrm{b})$ & 0.0655 & 0.0645 & 0.0130 \\
\hline Standard deviation on slope $\left(S_{b}\right)$ & $8.705 \times 10^{-4}$ & $3.2485 \times 10^{-4}$ & $9.852 \times 10^{-5}$ \\
\hline Intercept (a) & $6.75 \times 10^{-3}$ & $4.999 \times 10^{-4}$ & $6.999 \times 10^{-3}$ \\
\hline Standard deviation on intercept $\left(\mathrm{S}_{\mathrm{a}}\right)$ & $1.443 \times 10^{-3}$ & $1.347 \times 10^{-3}$ & $2.614 \times 10^{-3}$ \\
\hline Standard error on estimation $\left(\mathrm{S}_{\mathrm{e}}\right)$ & $1.376 \times 10^{-3}$ & $1.2841 \times 10^{-3}$ & $2.492 \times 10^{-3}$ \\
\hline Correlation coefficient (r) & 0.9999 & 0.9996 & 0.9996 \\
\hline Relative standard deviation, $\%$ & 0.2428 & 1.350 & 1.542 \\
\hline 0.05 level & 0.2791 & 0.15 & 1.773 \\
\hline 0.01 level & 0.4378 & 2.43 & 2.780 \\
\hline$\%$ Error in bulk samples & 0.10 & 0.164 & 0.282 \\
\hline
\end{tabular}

\section{Conclusion}

The proposed methods exploit the various functional groups in PYRA molecule. The decreasing order of sensitivity $\left(\epsilon_{\max }\right)$ among the proposed methods are (Method A $>$ Method B > Method C) respectively. The concomitants which do not contain the functional groups chosen in the present investigation do not interfere in the color development by proposed methods. Thus the proposed methods are simple, sensitive and selective with reasonable precision and accuracy and constitute better alternatives to the reported ones in the assay of PYRA in bulk form and pharmaceutical formulations (Table 3).

Table 3. Assay of PYRA in pharmaceutical formulations

\begin{tabular}{|c|c|c|c|c|c|c|c|c|}
\hline \multirow{2}{*}{ 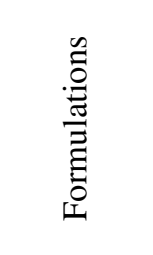 } & \multirow{2}{*}{ 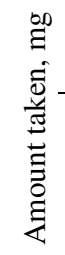 } & \multicolumn{4}{|c|}{ Amount found by proposed Methods } & \multicolumn{3}{|c|}{$\begin{array}{l}\text { Percentage recovery by } \\
\text { proposed methods }\end{array}$} \\
\hline & & $\begin{array}{l}\text { Method } \\
\text { A }\end{array}$ & $\begin{array}{l}\text { Method } \\
\text { B }\end{array}$ & Method C & $\begin{array}{l}\text { Reference } \\
\text { method }\end{array}$ & $\begin{array}{l}\text { Method } \\
\text { A }\end{array}$ & $\begin{array}{l}\text { Method } \\
\text { B }\end{array}$ & $\begin{array}{l}\text { Method } \\
\text { C }\end{array}$ \\
\hline Tablet I & 25 & $\begin{array}{l}24.66 \pm 0.55 \\
F=1.528 \\
t=0.9012\end{array}$ & $\begin{array}{l}24.75 \pm 0.52 \\
F=2.609 \\
t=0.8914\end{array}$ & $\begin{array}{l}24.8 \pm 0.45 \\
F=3.4844 \\
t=0.8055\end{array}$ & $25.1 \pm 0.84$ & $99.81 \pm 0.48$ & $99.72 \pm 0.68$ & $99.69 \pm 0.98$ \\
\hline Tablet II & 25 & $\begin{array}{l}24.69 \pm 0.46 \\
F=1.9357 \\
t=0.6613\end{array}$ & $\begin{array}{l}24.73 \pm 0.28 \\
F=2.25 \\
t=0.80\end{array}$ & $\begin{array}{l}24.59 \pm 0.25 \\
F=2.82 \\
t=1.27\end{array}$ & $24.99 \pm 0.42$ & $99.77 \pm 0.77$ & $99.81 \pm 0.83$ & $99.74 \pm 0.69$ \\
\hline Tablet III & 25 & $\begin{array}{l}24.55 \pm 0.45 \\
F=3.320 \\
t=1.0910\end{array}$ & $\begin{array}{l}24.71 \pm 0.31 \\
F=3.253 \\
t=0.50\end{array}$ & $\begin{array}{l}24.48 \pm 0.42 \\
F=1.777 \\
t=0.98\end{array}$ & $24.92 \pm 0.56$ & $99.61 \pm 0.95$ & $99.69 \pm 0.80$ & $99.49 \pm 0.86$ \\
\hline Tablet IV & 25 & $\begin{array}{l}25.10 \pm 0.28 \\
F=3.719 \\
t=0.8448\end{array}$ & $\begin{array}{l}24.69 \pm 0.19 \\
F=3.792 \\
t=0.96\end{array}$ & $\begin{array}{l}24.63+0.31 \\
F=1.753 \\
t=1.63\end{array}$ & $24.95 \pm 0.37$ & $99.69 \pm 0.98$ & $99.82 \pm 0.44$ & $99.88 \pm 0.88$ \\
\hline
\end{tabular}




\section{References}

1 The Merck Index, Merck \&Co Inc, New York, Ed., 2001, 13, 1803.

2 Aly F A, Mikrochim Acta, 1993, 100, 187-192.

3 Prasada Rao K V S, Nagaraju P., Prabhakar G, Begum J and Rasheed A, J Inst Chemists, 2004, 76, 19.

4 Matsuda R, Yamamiya T, Tatsuzawa M, Ejima A and Takai N, J Chromatogr., A 1979, 173, 75.

5 Hesses, Christof, Lang and Erich, GIT Spez Chromatogr., 1996, 16, 100.

6. Angelo H R, Herrstedt and Erich J, GIT Spez Chromatogr B., 1989, 496, 472.

7. Hattori H, Seno H, Ishil A, Yamada T and Suzuki O, Nippon Lyo Masu Supekutoru Gakkai Koenshu., 1998, 23,137.

8 Li Wan Po A and Irwin W, J High Resolut, Chromatogr., 1979, 2, 623.

$9 \quad$ Kaniewska T and Wejman W, Pol Farm, 1974, 30, 763.

10 Eblant-Goragia A, Balant L P Gent C and R. Eisele R, Ther Drug Monit., 1985, 7229.

11 Shehata I A, El-Ashry F, Sherbeny S M, EL Sherbeny M A and Belal F, J Pharm Biomed Anal, 2000, 22, 729-737.

12 Hassan S M, Belal F, Ibrahim F and Aly F A, Talanta, 1989, 36, 557.

13 Belal F, Ibrahim, Hassan S M and. Aly F A, Anal Chim Acta, 1991, 55, 103.

14 Kumazawa T, Seno H., Watanabe S, Kanako H, Hideki H, Akira S and Keizo O, $J$ Mass Spectrom., 2000, 35, 1091.

15 Clean S, Kane E J O and Smyth W F, J Chromatogr B Biomed Sci Appl., 2000, 740, 141.

16 Maurev H and Pfleger K, J Chromatogr., 1985, 306, 125.

17 Cailleux A, Turcant A, Premel-Cabic A and Allain P, J Chromatogr Sci., 1981, 19, 163.

18 El-Sherif Z. A., EL - Zeany B, EL-Houssinl O M, Rashed M S and Aboul-Enein H Y, Biomed Chromatogr., 2004, 18(3),143.

19 Janiszewski J, Schneider R P, Haffmaster K, Swyden, M, Wells D and Fouda H, Mass Spectrom., 1997, 11(9), 1033. 


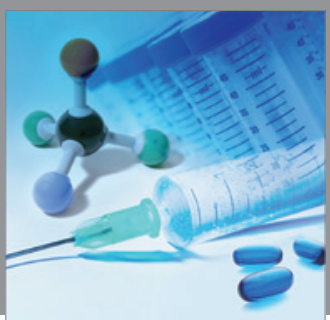

International Journal of

Medicinal Chemistry

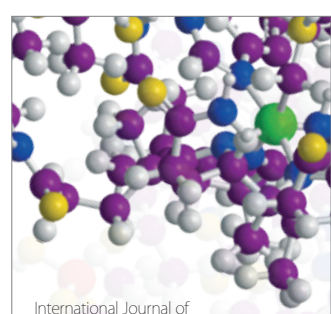

Carbohydrate Chemistry

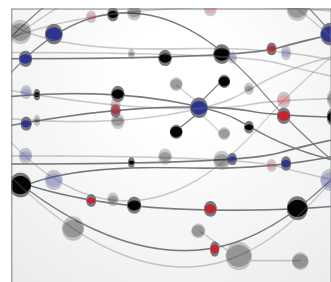

The Scientific World Journal
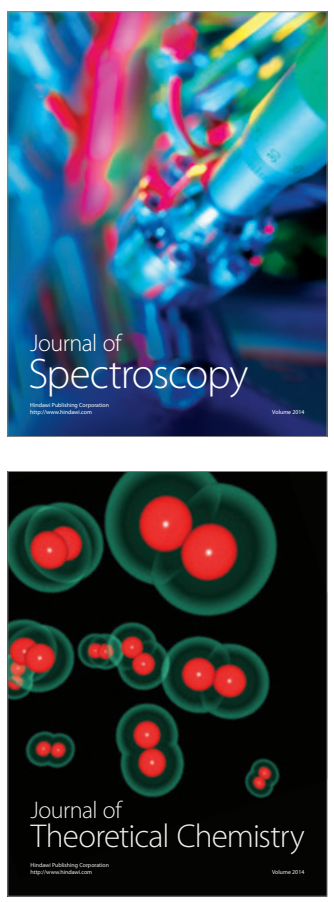
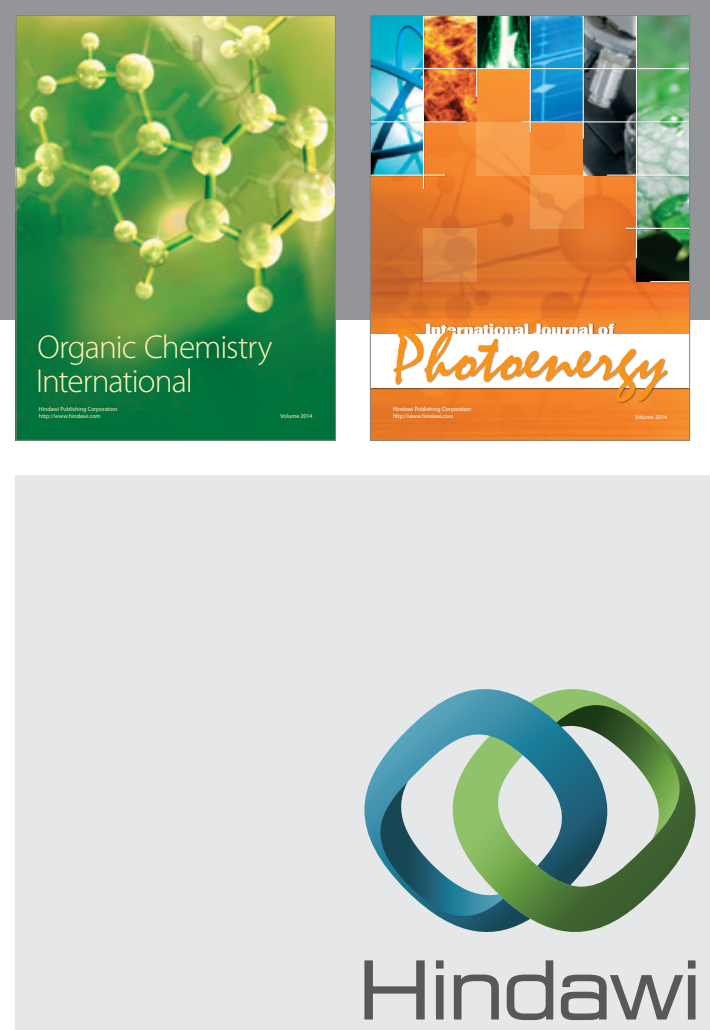

Submit your manuscripts at

http://www.hindawi.com
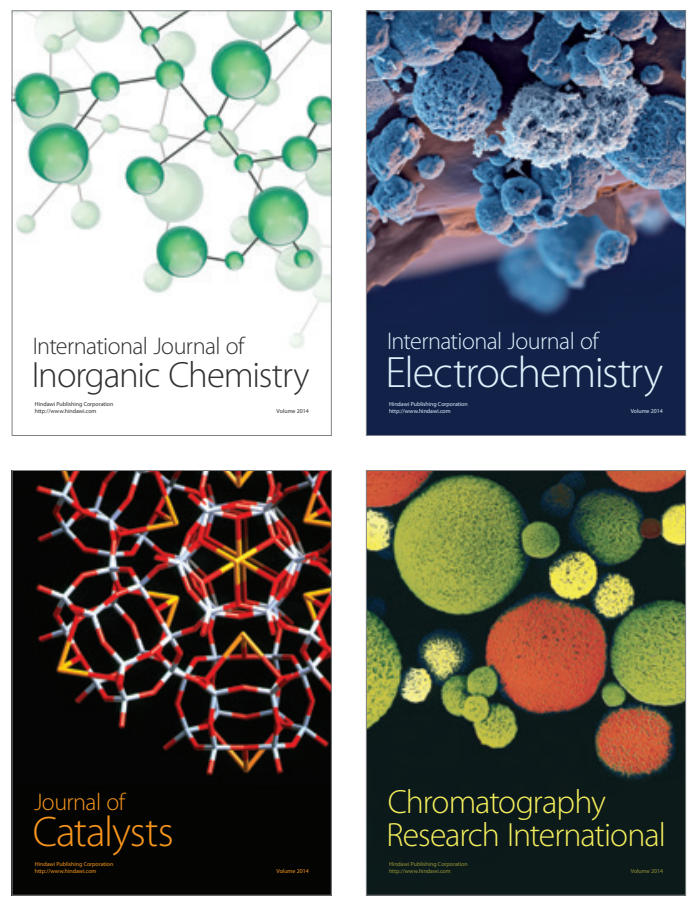
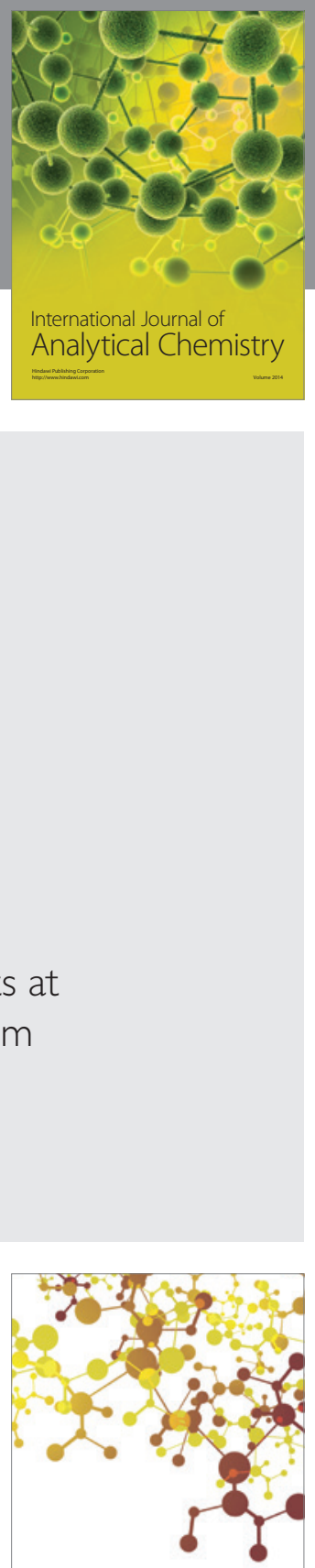

Journal of

Applied Chemistry
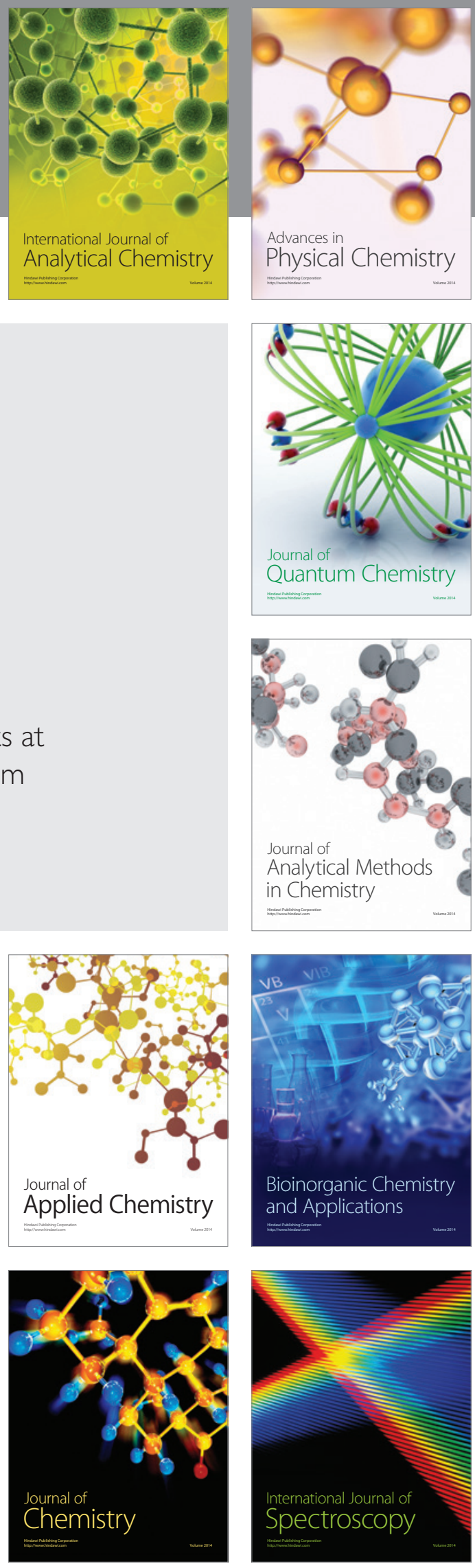